\title{
Paleogene deepwater mass composition of the tropical Pacific and implications for thermohaline circulation in a greenhouse world
}

\author{
Deborah J. Thomas and Mitchell Lyle \\ Department of Oceanography, Texas AङM University, College Station, Texas 77843, USA (dthomas@ocean.tamu.edu)
}

\author{
Theodore C. Moore Jr. and David K. Rea \\ Department of Geological Sciences, University of Michigan, Ann Arbor, Michigan, 48109, USA
}

[1] The Pacific Ocean likely exerted the greatest marine influence on climate during the greenhouse interval of the Paleogene. The first step toward assessing the role of Pacific deepwater circulation in global heat transport is a comprehensive reconstruction of deepwater mass composition and circulation patterns. We present new deepwater mass Nd isotope data from ODP Leg 199 Sites 1215, 1217, 1219, and 1221 to augment the existing coverage provided by ferromanganese crust and fossil fish debris data. The new data corroborate the notion that the Pacific Ocean operated in a bimodal pattern with deepwater sources in both the Southern Ocean and North Pacific for much of the early to middle Paleogene. In addition, the data indicate that there was little to no influence of Atlantic waters on the deepwater composition of the tropical Pacific. The available deepwater $\mathrm{Nd}$ isotope data provide refined constraints on the geographic and depth range of influence of both a Southern Ocean and North Pacific deepwater mass. From $~ 65$ to $45 \mathrm{Ma}$, the deep tropical Pacific was the mixing location of deep waters sourced from the Southern Ocean and the North Pacific. The Southern Ocean deepwater mass extended from $\sim 1800 \mathrm{~m}$ to abyssal depths. Until 53.6 Ma it circulated northward in the western Pacific at least as far as the paleolocation of Fe-Mn Crust CLD01 $\left(\sim 5^{\circ} \mathrm{N}\right.$ paleolatitude $)$ and in the eastern portion of the Pacific as far as Site $1215\left(\sim 10^{\circ} \mathrm{N}\right.$ paleolatitude). A North Pacific deepwater mass extended from at least $\sim 2400 \mathrm{~m}$ to $2900 \mathrm{~m}$ water depth from $\sim 65$ to $54 \mathrm{Ma}$, south to Shatsky Rise (paleolatitude $\sim 10-15^{\circ} \mathrm{N}$ ), and possibly as far as Site 1215 , $700 \mathrm{~km}$ to the south of Shatsky Rise Sites 1209 and 1211.

Components: 8190 words, 4 figures, 2 tables.

Keywords: ODP Leg 199; Nd isotopes; deepwater circulation.

Index Terms: 4962 Paleoceanography: Thermohaline.

Received 9 July 2007; Revised 13 September 2007; Accepted 7 November 2007; Published 2 February 2008.

Thomas, D. J., M. Lyle, T. C. Moore Jr., and D. K. Rea (2008), Paleogene deepwater mass composition of the tropical Pacific and implications for thermohaline circulation in a greenhouse world, Geochem. Geophys. Geosyst., 9, Q02002, doi:10.1029/ 2007GC001748. 


\section{Introduction}

[2] The production and flow of deepwater masses is a key component of heat transport in the modern climate system. The present regime of deepwater or meridional overturning circulation (MOC) is characterized by deepwater formation in the North Atlantic and the Southern Ocean, while the North Pacific is characterized by slow deepwater renewal. Downwelling appears to be weak or absent in the modern North Pacific because of low surface water salinities ( $\sim 33 \mathrm{ppt}$ as compared to $\sim 35 \mathrm{ppt}$ in the North Atlantic) [e.g., Levitus, 1982], and the Bering Strait sill does not permit denser Arctic bottom waters to enter the North Pacific [Tomczak and Godfrey, 1994]. In addition, bottom waters formed in the Ross Sea (the Pacific sector of the Southern Ocean) are prevented from flowing northward into the Pacific basin by the eastward flow of the Antarctic circumpolar current and the midocean ridge separating the Pacific and Antarctic plates [Tomczak and Godfrey, 1994].

[3] The key role of the North Atlantic in modern MOC is one of the reasons why most studies of ancient MOC have focused on the role of the Atlantic. However, the present bipolar mode of MOC that includes downwelling in the North Atlantic is a geologically recent development, the culmination of millions of years of tectonic and climatic evolution [e.g., Mountain and Miller, 1992; Pak and Miller, 1992; Wright and Miller, 1996; Via and Thomas, 2006; Thomas and Via, 2007]. In order to understand the role, if any, of deepwater circulation in ancient climate systems, we must address the role of the Pacific Ocean. Obviously the Pacific was a much larger basin than the Atlantic during the Cretaceous and early Cenozoic than it is today, and with the Arctic -North Atlantic connection much more restricted in the Paleogene [Moran et al., 2006], the Pacific should have exerted a much larger influence on global climate than in the modern regime.

[4] The first step toward assessing the role of the Pacific MOC in global heat transport is a comprehensive reconstruction of deepwater mass composition and circulation patterns. This has proven difficult because of the dearth of complete Pacific records and relatively poor carbonate preservation in Pacific sediments. However a growing body of $\mathrm{Nd}$ isotope data from ferromanganese crusts and fossil fish debris is beginning to provide a reconstruction of the ancient Pacific water column. Recent Nd isotope evidence suggests that a bipolar mode of MOC may have operated in the Pacific during a portion of the early Cenozoic [Thomas, 2004]. Deep-sea Nd isotope data from Shatsky Rise in the present-day northwestern Pacific Ocean suggest a fundamental switch in deepwater production from the Southern Ocean to the North Pacific beginning $\sim 65 \mathrm{Ma}$ [Thomas, 2004]. The data indicate that production of North Pacific deep waters lasted $\sim 20$ million years, and coincided with the warmest climatic interval of the Cenozoic Era. However, this scenario is based on data from one location, and crust records from varied water depths further south do not indicate the influence of a North Pacific water mass [e.g., Ling et al., 1997; van de Flierdt et al., 2004]. To better assess the existence and strength of a North Pacific deepwater contribution to the immense Pacific circulation regime we must examine additional locations that may have been influenced by such a contribution. An additional factor that must be constrained before we can consider the effects of a bimodal MOC in the Paleogene Pacific is the possible influence of Atlantic deep waters that may have entered the deep tropical Pacific via the open Caribbean gateway.

[5] Here we revisit the notion of North Pacific deepwater production during the early Cenozoic by examining the composition of deep waters at additional locations in the tropical Pacific. We present new data spanning the time interval $\sim 56$ to $31 \mathrm{Ma}$ from Ocean Drilling Program Leg 199 (equatorial Pacific) Sites 1215, 1217, 1219, and 1221 to augment the early Cenozoic database of Pacific deepwater mass composition. These sites lie well to the east and slightly south of Shatsky Rise, providing expanded coverage of the tropical Pacific during the Paleogene (Figure 1). The location of these sites is ideal for two reasons: they enable us to delineate the southern extent of the influence of a North Pacific deepwater mass and to investigate any possible contributions of Caribbean throughflow to the deepwater circulation in the Pacific. In addition, the Leg 199 Sites underwent thermal subsidence from $\sim 2800$ to $4500 \mathrm{~m}$ water depth as the seafloor cooled, expanding the depth range of the tropical Pacific deepwater mass reconstruction.

\section{Methods}

\subsection{Site Selection}

[6] ODP Sites 1215, 1217, 1219, and 1221 were drilled as part of Leg 199, the Paleogene Equatorial 

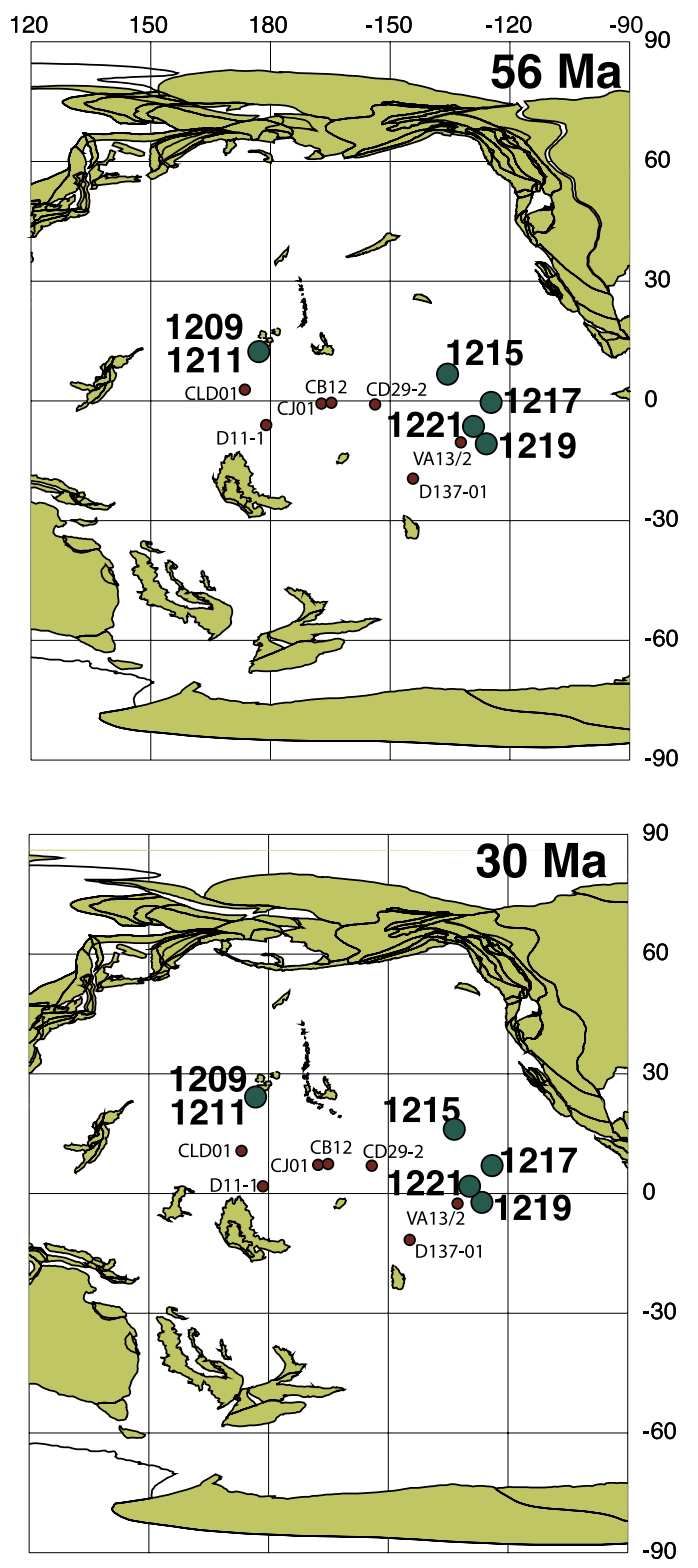

Figure 1. Paleogeographic reconstructions of $56 \mathrm{Ma}$ and $30 \mathrm{Ma}$ (Ocean Drilling Stratigraphic Network, http://www.odsn.de) indicating the ancient locations of the ODP Leg 199 Sites investigated in this study (labeled green dots), as well as the locations of the ferromanganese crust records discussed in the text and listed in Table 2 (red dots).

Transect expedition (Figure 1). This transect of sites was designed to investigate the evolution of tropical Pacific surface current and wind regime during the transition from the early Paleogene "greenhouse" to the late Paleogene "icehouse" climate regimes. Site $1215\left(26^{\circ} 02^{\prime} \mathrm{N}, 5396 \mathrm{~m}\right.$ water depth) is the northernmost site in the transect, and Site $1219\left(7^{\circ} 48^{\prime} \mathrm{N}, 5063 \mathrm{~m}\right.$ water depth) is the southernmost site. All four sites were drilled on basement $\sim 56$ million years old, and it is assumed that the water depth of each site deepened from $\sim 2800 \mathrm{~m}$ to present water depths through simple thermal subsidence [Lyle et al., 2002].

[7] We selected the four Leg 199 Sites to investigate the composition of tropical Pacific deepwater masses and the vertical structure of the water column during the Eocene. The tropical location of these sites is useful for tracking the relative influence of deep waters formed in the high southern latitudes versus those inferred to have formed in the North Pacific [Thomas, 2004]. In addition, Sites 1217,1219 and 1221 are ideally situated to monitor the potential influence of deepwater exchange through the Caribbean gateway. The paleogeographic locations of the drill sites were obtained with the Ocean Drilling Stratigraphic Network plate tectonic reconstruction advanced mapping tool (http://www.odsn.de). Motion of the Pacific plate was calculated using the magnetic reference frame of Harrison and Lindh [1982]. While Pares and Moore [2005] found that the northward motion of the Pacific plate was likely less than indicated in the plate tectonic reconstructions because of southward motion of the Hawaiian hot spot plume, the positions of the drill sites relative to each other would have remained constant because they are all located on the Pacific Plate.

\subsection{Age Model}

[8] The ages assigned to the samples are based on shipboard magnetostratigraphic and biostratigraphic data (calcareous nannofossils and radiolaria) [Lyle et al., 2002]. Each datum was attributed a numerical age from Cande and Kent [1995]. Linear sedimentation rates were calculated between datums to yield a numeric age for each sample.

\subsection{Nd Isotopes as a Paleoceanographic Proxy}

[9] The $\mathrm{Nd}$ isotopic composition of seawater, expressed as $\varepsilon_{\mathrm{Nd}}$, (the ${ }^{143} \mathrm{Nd} /{ }^{144} \mathrm{Nd}$ value of a geologic sample normalized to the bulk earth [DePaolo and Wasserburg, 1976]), varies on a basin scale as well as within individual ocean basins [e.g., Piepgras and Wasserburg, 1987; Piepgras and Jacobsen, 1988; Jeandel, 1993; Jeandel et al., 1998; Amakawa et al., 2000]. Seawater $\varepsilon_{\mathrm{Nd}}$ variations result from differences in weathering of subaerially exposed rocks that drain into a given ocean basin [Goldstein and Jacobsen, 1988]. Intermediate-water and deepwater masses acquire the $\varepsilon_{\mathrm{Nd}}$ composition of the surface waters 
in the region of subduction or downwelling [Goldstein and Jacobsen, 1988; Elderfield et al., 1990; Halliday et al., 1992; Sholkovitz, 1993]. Subsequently, the initial $\varepsilon_{\mathrm{Nd}}$ of a particular water mass is altered through mixing with other water masses [e.g., Piepgras and Wasserburg, 1982, 1987; Piepgras and Jacobsen, 1988; Jeandel, 1993; Shimizu et al., 1994; Jeandel et al., 1998; Amakawa et al., 2000]; however, provenance information is retained because of the short oceanic residence time of $\mathrm{Nd}(\sim 1000$ years [e.g., Tachikawa et al., 1999]) relative to oceanic mixing rates ( 1500 years [Broecker et al., 1960]).

[10] The $\mathrm{Nd}$ isotopic composition of individual water masses is derived from the composition of dissolved materials draining into the source region [Goldstein and Jacobsen, 1988; Elderfield et al., 1990; Sholkovitz, 1993]. For example, North Atlantic Deep Water (NADW) forms as dense waters from the Nordic Seas $\left(\varepsilon_{\mathrm{Nd}} \sim-9\right)$ flow southward and mix with sinking waters in the Labrador Sea with a surface $\varepsilon_{\mathrm{Nd}}$ value as low as approximately -26 [Piepgras and Wasserburg, 1987]. The resulting water mass has an $\varepsilon_{\mathrm{Nd}}$ signature of approximately -12 to -13 , which can be used to track NADW throughout its deep-sea transit.

[11] Modern Southern Ocean waters (both Antarctic Intermediate Water and Antarctic Bottom Water) have a more radiogenic signature than NADW, derived from the mixing of NADW with Pacific waters flowing eastward through the Drake Passage within the Circumpolar current [Piepgras and Wasserburg, 1982]. Thus Antarctic waters have an $\varepsilon_{\mathrm{Nd}}$ value of approximately -9 [Piepgras and Wasserburg, 1982].

[12] The most radiogenic $\varepsilon_{\mathrm{Nd}}$ values are found in the surface waters of the North and South Pacific, which have a characteristically radiogenic signature of $\sim 0$ to -4 [Piepgras and Wasserburg, 1982; Piepgras and Jacobsen, 1988; Shimizu et al., 1994]. This reflects the average fluvial input to the Pacific of -2.9 to -3.7 [Goldstein and Jacobsen, 1988]. However, depth profiles of $\mathrm{Nd}$ isotopic composition indicate considerable stratification of South Pacific waters compared to the North Pacific. Analyses from the South Pacific indicate very radiogenic surface waters of $\varepsilon_{\mathrm{Nd}} \sim 0$ underlain by much more nonradiogenic $\varepsilon_{\mathrm{Nd}}$ values of approximately -8 at $4500 \mathrm{~m}$ water depth [Piepgras and Wasserburg, 1982]. The more negative, nonradiogenic bottom water signature reflects the northward flow of Antarctic bottom waters into the Pacific [Piepgras and Jacobsen, 1988].
[13] North Pacific depth profiles of $\mathrm{Nd}$ isotopic composition are significantly different than those in the South Pacific. While there is a slight trend toward more negative values at depth, much less stratification of $\varepsilon_{\mathrm{Nd}}$ values is evident in North Pacific profiles despite the existence of distinct intermediate, deep, and bottom water masses [e.g., Tomczak and Godfrey, 1994]. The dominance of "Pacific" $\varepsilon_{\mathrm{Nd}}$ values and the absence of an $\mathrm{AABW} \varepsilon_{\mathrm{Nd}}$ signature (i.e., approximately -8 ) in the bottom waters of the North Pacific is the consequence of very slow deepwater renewal in this region. Thus vertical exchange of $\mathrm{Nd}$ between Pacific intermediate waters and the underlying deep and bottom water masses is able to dominate over advective transport of the $\mathrm{AABW} \varepsilon_{\mathrm{Nd}}$ signal, imparting the relatively radiogenic $\varepsilon_{\mathrm{Nd}}$ signature (approximately -4) to the deep North Pacific despite the lack of downwelling in the region.

[14] Temporal variations in the deepwater radiogenic isotope composition at a given location may result from changes in the contribution of deep waters from a given source region with an invariant $\mathrm{Nd}$ isotopic composition (change in circulation pattern or water mass mixing), changes in the composition of $\mathrm{Nd}$ draining into the deepwater formation region (weathering changes), or a combination of both factors. Thus supporting data and geologic/paleoceanographic context must be used to determine the cause of radiogenic isotope changes at a given location.

[15] Fe-Mn crusts, authigenic Fe-Mn minerals in bulk sediment, foraminiferal calcite, and fish debris all record the $\mathrm{Nd}$ isotopic composition of ocean waters at the seafloor. This investigation employs the teeth and bones of fossil fish, which are useful for paleo-Nd investigations because of their relatively high $\mathrm{Nd}$ concentrations (100-1000 ppm) [e.g., Wright et al., 1984; Shaw and Wasserburg, 1985; Staudigel et al., 1985], as well as their resistance to dissolution in corrosive bottom waters. In addition, they are present, albeit rare, in most deep-sea sedimentary sections, providing the opportunity for widespread geographic and stratigraphic coverage within a well-dated biostratigraphic framework.

[16] The teeth and bones of living fish do not contain $\mathrm{Nd}$, thus where the fish dwelt and swam during its lifetime has no bearing on the $\varepsilon_{\mathrm{Nd}}$ of fossil fish debris [e.g., Wright et al., 1984; Staudigel et al., 1985]. Fish debris acquires enhanced $\mathrm{Nd}$ concentrations through postmortem trapping at the sediment/water interface [e.g., Staudigel et al., 
1985; Reynard et al., 1999]. Rare earth elements (REEs) are preconcentrated by settling organic and oxyhydroxide particles, and trapping by fish debris is accomplished via adsorption and substitution on the seafloor [e.g., Reynard et al., 1999]. Thus the fossil material records the $\mathrm{Nd}$ isotopic composition of oceanic deep and bottom waters [e.g., Wright et al., 1984; Shaw and Wasserburg, 1985; Staudigel et al., 1985; Martin and Haley, 2000; Martin and Scher, 2004; Thomas, 2005]. Fish bones record and preserve the same signal as fish teeth [Thomas and Via, 2007].

\subsection{Analytical Details}

[17] We hand picked and cleaned all fish teeth/ bone samples using a strong reductive/oxidative cleaning protocol to remove the oxide coating and any residual organic material (modified from Boyle [1981] and Boyle and Keigwin [1985]), and then dissolved the samples in $2 \mathrm{~N}^{-\mathrm{HNO}_{3}}$. The REE suite of the teeth was isolated with RE Spec chemistry, and $\mathrm{Nd}$ was separated from the other REE with 2-methyllactic acid chemistry. All samples were analyzed as $\mathrm{NdO}^{+}$with a monitor beam $\left({ }^{144} \mathrm{Nd}^{16} \mathrm{O}\right)$ of $\sim 500 \mathrm{mV}$ on a $\mathrm{GV}$ Sector 54 thermal ionization mass spectrometer (TIMS) at the University of North Carolina at Chapel Hill. External analytical precision based upon replicate analysis of the international standard $\mathrm{JNd}_{\mathrm{i}}$ [Tanaka et al., 2000] yielded $0.512111 \pm 0.000010(2 \sigma)$ $(\mathrm{n}=30)$ which is calibrated relative to the La Jolla standard $(0.511858)$ as 0.512116 . The total procedural blank is $\sim 15 \mathrm{pg}$ and is considered negligible. Replicate analyses of several samples yielded $\mathrm{Nd}$ isotope values within error limits.

[18] All data presented in this paper are expressed as $\varepsilon_{N d}(t)$ values, which normalizes to the bulk earth value and corrects for age (any in situ decay of ${ }^{147} \mathrm{Sm}$ once incorporated into the biogenic apatite). To correct for any postburial decay of ${ }^{147} \mathrm{Sm}$, we applied a mean ${ }^{147} \mathrm{Sm} /{ }^{144} \mathrm{Nd}$ value of 0.131 obtained from all Pacific samples analyzed to date. This value lies within the maximum range of fish debris ${ }^{147} \mathrm{Sm} /{ }^{144} \mathrm{Nd}$ found in the literature [e.g., Martin and Haley, 2000].

\section{Results}

[19] In general, Leg 199 samples exhibit low variability and few significant trends, with all values from the four sites lying between approximately -3.5 and -5.5 (Figure 2 and Table 1). We analyzed 8 samples from Site 1215, all of which recorded $\varepsilon_{\mathrm{Nd}}(\mathrm{t})$ values between -3.4 and -4.5 . Epsilon values decrease from -4.2 at $65.52 \mathrm{mcd}$ $(55.58 \mathrm{Ma})$ to -4.5 at $58.07 \mathrm{mcd}(54.99 \mathrm{Ma})$, and then increase to -3.4 at the top of the analyzed section $28.06 \mathrm{mcd}$; $49.30 \mathrm{Ma}$ ). The 9 samples analyzed from Site 1217 exhibit a general decrease from -4.3 at the base of the section $(130.06 \mathrm{mcd}$; $53.64 \mathrm{Ma})$ to -4.7 at $25.16 \mathrm{mcd}(31.75 \mathrm{Ma})$, with a maximum value of -4.0 at $52.42 \mathrm{mcd}(37.81 \mathrm{Ma})$. Hole $1219 \mathrm{~A} \varepsilon_{\mathrm{Nd}}(\mathrm{t})$ values generally decrease from -4.3 at $268.53 \mathrm{mcd}(52.78 \mathrm{Ma})$ to -5.0 at $131.99 \mathrm{mcd}(29.97 \mathrm{Ma})$, with the maximum value of -4.1 occurring at $144.75 \mathrm{mcd}(30.91 \mathrm{Ma})$ and the minimum value of -5.6 at $160.2 \mathrm{mcd}$ $(30.75 \mathrm{Ma})$. The 14 Site 1221 values vary between -3.6 and -4.9 with little discernable trend over the $\sim 150 \mathrm{~m}$ of composite section analyzed $(\sim 20 \mathrm{Ma})$.

\section{Discussion}

\subsection{Pacific Deepwater Provenance During the Paleogene}

[20] The majority of the Leg $199 \mathrm{Nd}$ isotope data is characterized by $\varepsilon_{\mathrm{Nd}}(\mathrm{t})$ values that lie within a narrow range of approximately -4 to -5 (Figure 2). This similarity in values persists across the geographic range of sites (with the notable exception of Site 1215 from $\sim 54$ to $49 \mathrm{Ma}$, and Site 1221 at $37.9 \mathrm{Ma}$, discussed below), but also through the $\sim 25$ Ma time span investigated (Figure 3). It is also important to note that the relative constancy of deepwater $\mathrm{Nd}$ isotope composition persists through significant deepening of the four sites during the thermal subsidence of the seafloor (the water depth at each site is depicted by the brown line in each panel of Figure 3). The Leg 199 sites investigated here were drilled on seafloor that formed $\sim 56$ Ma [Lyle et al., 2002], thus the older, more deeply buried portions of each record were characterized by "upper" deepwater depths $(\sim 2.8 \mathrm{~km})$ and the more recently deposited portions were situated at "lower" deepwater depths $(\sim 4.5 \mathrm{~km})$. The overall consistency of deepwater composition for $\sim 25 \mathrm{Ma}$ indicates that the Leg 199 Sites were bathed by a common deepwater mass that encompassed the depth range of at least 2.8 to $4.5 \mathrm{~km}$ in the eastern tropical Pacific.

[21] Comparison of the Leg 199 deepwater $\varepsilon_{\mathrm{Nd}}(\mathrm{t})$ values to those from Shatsky Rise [Thomas, 2004] provides additional details of the water mass composition of the deep Pacific during the Paleogene 

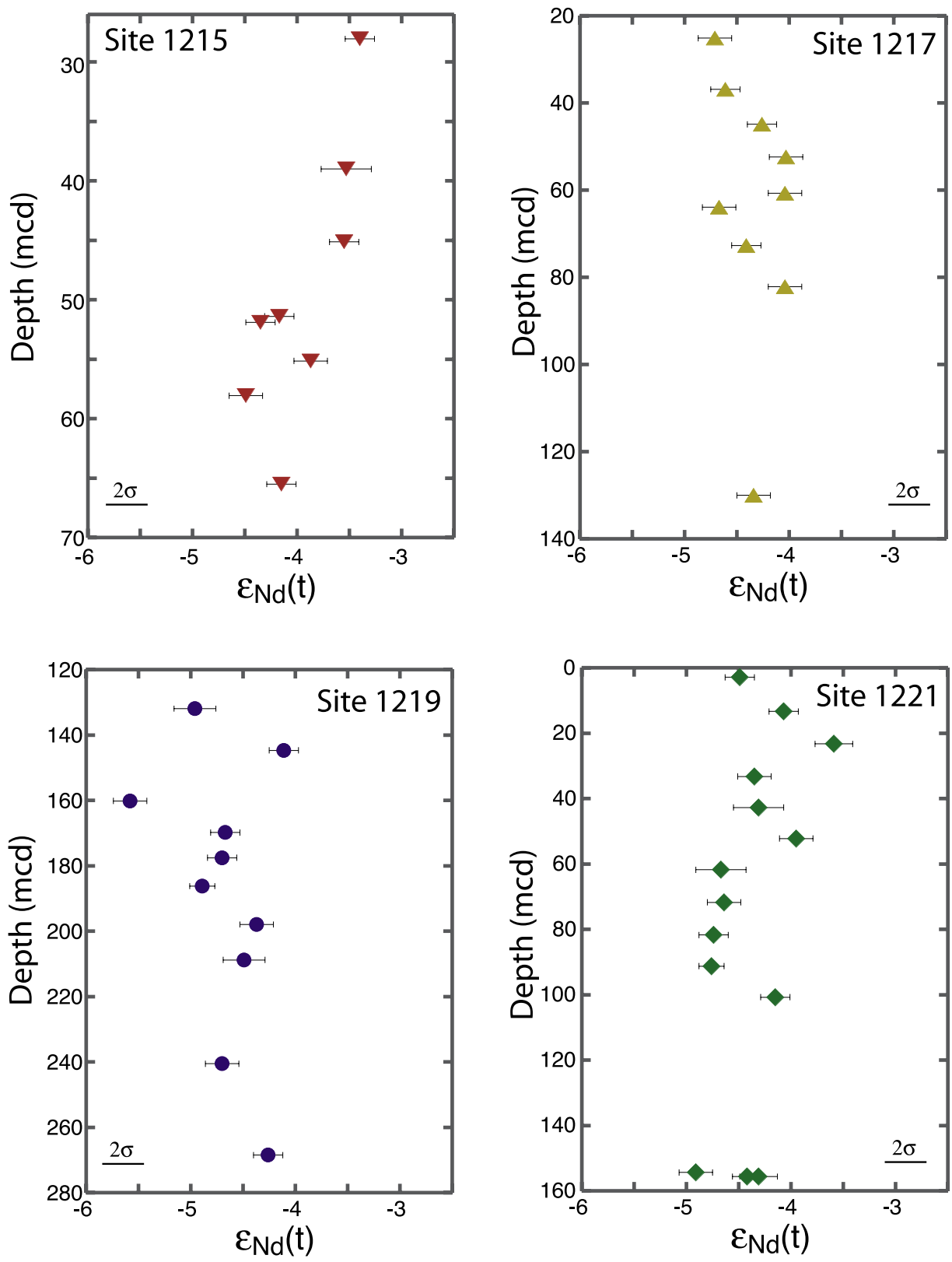

Figure 2. Nd isotope data generated for this investigation from ODP Sites 1215, 1217, 1219 and 1221. All data are plotted versus meters composite depth (mcd) based on shipboard splicing of several holes into a more complete stratigraphic sequence. Error bars on individual samples indicate within-run precision, and the $2 \sigma$ error bar in the bottom of each panel represents the external precision based on replicate analysis of the JNdi standard. Replicate analyses are indicated by the average of the two values on the graphs.

(Figure 3). The range of $\mathrm{Nd}$ isotope values recorded by Shatsky Rise Sites 1209 and 1211 (paleowater depths of $\sim 2.4$ and $2.9 \mathrm{~km}$, respectively) is indicated by the light green shading in each panel of Figure 3. Shatsky Rise $\varepsilon_{\mathrm{Nd}}(\mathrm{t})$ data reflect radiogenic $\varepsilon_{N d}(t)$ values (approximately -3 to -3.5 ) from the beginning of the studied interval at $\sim 56 \mathrm{Ma}$ to $\sim 45 \mathrm{Ma}$, when the data trend toward less radiogenic values (approximately -4 to -5 ).
The majority of the Leg 199 data are significantly less radiogenic than the $\varepsilon_{\mathrm{Nd}}(\mathrm{t})$ values from Shatsky Rise until $\sim 42 \mathrm{Ma}$. This suggests that Shatsky Rise generally was bathed by a different deepwater mass than the Leg 199 Sites from $\sim 56$ to $42 \mathrm{Ma}$, and then shared a common deepwater mass once the Shatsky Rise data became less radiogenic after $45 \mathrm{Ma}$. 
Table 1. ODP Leg $199 \mathrm{Nd}$ Isotope Data Generated for This Study

\begin{tabular}{|c|c|c|c|c|}
\hline Sample & Depth, mcd & Age, Ma & ${ }^{143} \mathrm{Nd} /{ }^{144} \mathrm{Nd}$ & $\varepsilon_{\mathrm{Nd}}(\mathrm{t})$ \\
\hline $1215 \mathrm{~A}, 4-3,50-52 \mathrm{~cm}$ & 28.06 & 49.30 & $0.512443 \pm 7$ & $-3.40 \pm 14$ \\
\hline $1215 \mathrm{~A}, 5-4,13-15 \mathrm{~cm}$ & 39.01 & 53.35 & $0.512434 \pm 12$ & $-3.53 \pm 24$ \\
\hline $1215 \mathrm{~A}, 6-2,32-34 \mathrm{~cm}$ & 45.14 & 53.58 & $0.512433 \pm 7$ & $-3.55 \pm 14$ \\
\hline $1215 \mathrm{~B}, 6-1,15-17 \mathrm{~cm}$ & 51.39 & 54.06 & $0.512401 \pm 7$ & $-4.17 \pm 14$ \\
\hline $1215 \mathrm{~B}, 6-1,67-69 \mathrm{~cm}$ & 51.91 & 54.14 & $0.512392 \pm 8$ & $-4.35 \pm 16$ \\
\hline $1215 \mathrm{~B}, 7-2,40-42 \mathrm{~cm}$ & 55.15 & 54.59 & $0.512416 \pm 7$ & $-3.87 \pm 14$ \\
\hline $1215 \mathrm{~A}, 8-3,75-77 \mathrm{~cm}$ & 58.07 & 54.99 & $0.512384 \pm 8$ & $-4.49 \pm 16$ \\
\hline $1215 \mathrm{~A}, 9-2,20-22 \mathrm{~cm}$ & 65.52 & 55.58 & $0.512401 \pm 7$ & $-4.15 \pm 14$ \\
\hline 1217A, $4-1,40-42 \mathrm{~cm}$ & 25.16 & 31.75 & $0.512383 \pm 8$ & $-4.71 \pm 16$ \\
\hline 1217A, 5-1, 40-42 cm & 36.9 & 35.35 & $0.512386 \pm 7$ & $-4.61 \pm 14$ \\
\hline $1217 \mathrm{~A}, 6-1,40-42 \mathrm{~cm}$ & 44.91 & 36.23 & $0.512404 \pm 7$ & $-4.26 \pm 14$ \\
\hline $1217 \mathrm{~A}, 7-1,90-92 \mathrm{~cm}$ & 52.42 & 37.81 & $0.512415 \pm 8$ & $-4.03 \pm 16$ \\
\hline $1217 \mathrm{~A}, 8-1,50-52 \mathrm{~cm}$ & 60.7 & 39.77 & $0.512414 \pm 8$ & $-4.04 \pm 16$ \\
\hline $1217 \mathrm{~A}, 9-1,40-42 \mathrm{~cm}$ & 63.95 & 40.30 & $0.512381 \pm 8$ & $-4.67 \pm 16$ \\
\hline $1217 \mathrm{~A}, 10-1,45-47 \mathrm{~cm}$ & 72.71 & 41.17 & $0.512394 \pm 7$ & $-4.41 \pm 14$ \\
\hline $1217 \mathrm{~A}, 11-1,40-42 \mathrm{~cm}$ & 82.16 & 43.08 & $0.512413 \pm 8$ & $-4.04 \pm 16$ \\
\hline $1217 \mathrm{~A}, 16-1,40-42 \mathrm{~cm}$ & 130.06 & 53.64 & $0.512393 \pm 8$ & $-4.34 \pm 16$ \\
\hline $1219 \mathrm{~A}, 13-2,40-42 \mathrm{~cm}$ & 131.99 & 29.97 & $0.512371 \pm 10$ & $-4.96 \pm 20$ \\
\hline $1219 \mathrm{~A}, 14-3,30-32 \mathrm{~cm}$ & 144.75 & 30.75 & $0.512414 \pm 7$ & $-4.11 \pm 14$ \\
\hline $1219 \mathrm{~A}, 15-6,35-37 \mathrm{~cm}$ & 160.2 & 31.90 & $0.512358 \pm 8$ & $-5.58 \pm 16$ \\
\hline $1219 \mathrm{~A}, 16-5,45-47 \mathrm{~cm}$ & 169.89 & 32.57 & $0.512403 \pm 7$ & $-4.67 \pm 14$ \\
\hline $1219 \mathrm{~A}, 17-4,40-42 \mathrm{~cm}$ & 177.59 & 33.22 & $0.512383 \pm 7$ & $-4.70 \pm 14$ \\
\hline $1219 \mathrm{~A}, 18-2,40-42 \mathrm{~cm}$ & 186.23 & 35.23 & $0.512372 \pm 6$ & $-4.89 \pm 12$ \\
\hline $1219 \mathrm{~A}, 19-3,15-17 \mathrm{~cm}$ & 197.98 & 37.56 & $0.512398 \pm 8$ & $-4.37 \pm 16$ \\
\hline $1219 \mathrm{~A}, 20-3,50-52 \mathrm{~cm}$ & 208.83 & 39.33 & $0.512391 \pm 10$ & $-4.49 \pm 20$ \\
\hline $1219 \mathrm{~A}, 23-3,75-77 \mathrm{~cm}$ & 240.58 & 43.05 & $0.512379 \pm 8$ & $-4.70 \pm 16$ \\
\hline $1219 \mathrm{~A}, 26-1,10-12 \mathrm{~cm}$ & 268.53 & 52.78 & $0.512397 \pm 7$ & $-4.26 \pm 14$ \\
\hline $1221 \mathrm{~A}, 1-3,50-52 \mathrm{~cm}$ & 2.94 & 34.08 & $0.512393 \pm 7$ & $-4.51 \pm 14$ \\
\hline $1221 \mathrm{~A}, 2-3,50-52 \mathrm{~cm}$ & 13.38 & 35.81 & $0.512414 \pm 7$ & $-4.07 \pm 14$ \\
\hline $1221 \mathrm{~A}, 3-3,40-42 \mathrm{~cm}$ & 23.28 & 37.87 & $0.512438 \pm 9$ & $-3.59 \pm 18$ \\
\hline $1221 \mathrm{~A}, 4-3,40-42 \mathrm{~cm}$ & 33.28 & 39.43 & $0.512398 \pm 8$ & $-4.35 \pm 16$ \\
\hline $1221 \mathrm{~A}, 5-3,40-42 \mathrm{~cm}$ & 42.78 & 40.61 & $0.512400 \pm 12$ & $-4.31 \pm 24$ \\
\hline $1221 \mathrm{~A}, 6-3,40-42 \mathrm{~cm}$ & 52.28 & 41.71 & $0.512418 \pm 8$ & $-3.95 \pm 16$ \\
\hline $1221 \mathrm{~A}, 7-3,40-42 \mathrm{~cm}$ & 61.78 & 42.80 & $0.512380 \pm 12$ & $-4.67 \pm 24$ \\
\hline $1221 \mathrm{~A}, 8-3,40-42 \mathrm{~cm}$ & 71.78 & 43.63 & $0.512381 \pm 8$ & $-4.64 \pm 16$ \\
\hline $1221 \mathrm{~A}, 9-3,40-42 \mathrm{~cm}$ & 81.74 & 44.76 & $0.512376 \pm 7$ & $-4.74 \pm 14$ \\
\hline $1221 \mathrm{~A}, 10-3,40-42 \mathrm{~cm}$ & 91.28 & 46.01 & $0.512374 \pm 6$ & $-4.77 \pm 12$ \\
\hline $1221 \mathrm{~A}, 11-3,40-42 \mathrm{~cm}$ & 100.78 & 47.26 & $0.512405 \pm 7$ & $-4.16 \pm 14$ \\
\hline $1221 \mathrm{C}, 11-3,100-102 \mathrm{~cm}$ & 154.4 & 54.29 & $0.512363 \pm 8$ & $-4.90 \pm 16$ \\
\hline $1221 \mathrm{C}, 12-1,25-27 \mathrm{~cm}$ & 155.65 & 54.46 & $0.512388 \pm 7$ & $-4.41 \pm 14$ \\
\hline $1221 \mathrm{C}, 12-1,25-27 \mathrm{~cm}$ & 155.65 & 54.46 & $0.512394 \pm 9$ & $-4.30 \pm 18$ \\
\hline
\end{tabular}

[22] $\mathrm{Nd}$ isotope values from seven equatorial Pacific Fe-Mn crust records (locations indicated in Figure 1 and Table 2) support the geographic distinction in deepwater mass composition delineated by the ODP site fish debris records between the equatorial Pacific and Shatsky Rise (Figure 4). All of the crust data are less radiogenic than $\varepsilon_{N d}(t)$ values of approximately -4 , consistent with the distribution of $\mathrm{Nd}$ data from the Leg 199 Sites and less radiogenic than the Shatsky Rise values prior to $\sim 42 \mathrm{Ma}$. The northernmost crusts were recovered from $\sim 1^{\circ}$ to $5^{\circ}$ north of Site 1217 , while the rest lay to the south. All of the crusts were recovered from locations at least $11^{\circ}$ south of Shatsky rise and $5^{\circ}$ south of Site 1215 (Table 2). Because all of these crusts formed on the Pacific plate, the relative geographic distances between the modern crust and drill site locations should apply toward estimates of the ancient relative distances, and we have assumed that the sites backtracked consistently.

[23] An interesting feature of the Site 1215 record is that $\varepsilon_{N d}(t)$ values are much closer to the lower limit of Shatsky values from 53.6 to $49.3 \mathrm{Ma}$ than the other Leg 199 Sites. This suggests that the location of Site 1215 may have been bathed by the 


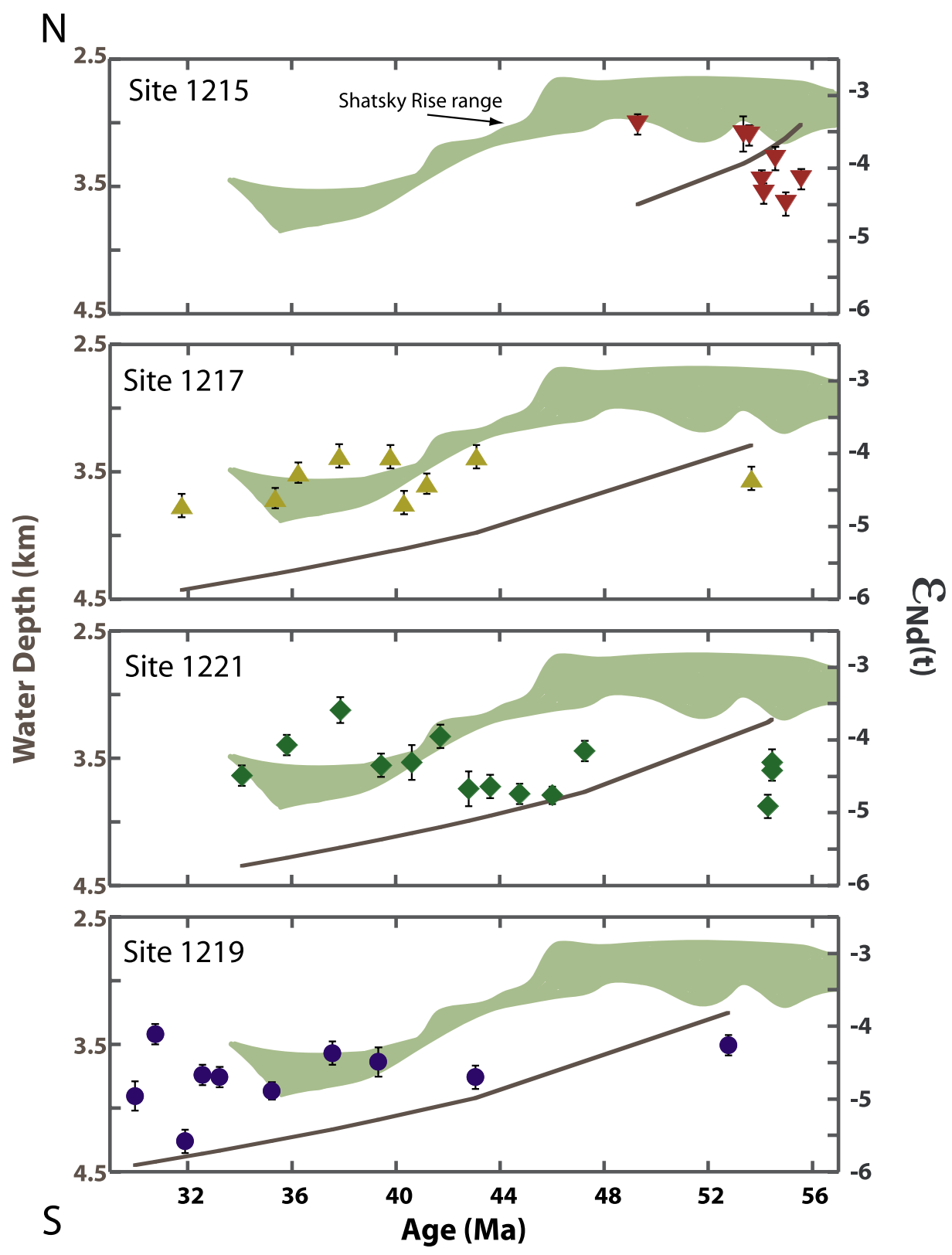

Figure 3. Leg $199 \mathrm{Nd}$ isotope data plotted as a function of age. The panels are arranged vertically in a north to south progression with Site 1215 lying at the northernmost end of the transect and Site 1219 at the southern extent. In addition, the backtracked water depth is plotted against age to demonstrate the consistency of the $\mathrm{Nd}$ isotope signal even through significant thermal subsidence of the seafloor through the Paleogene. The light green shading represents the range of $\varepsilon_{\mathrm{Nd}}(\mathrm{t})$ values at Shatsky Rise Sites 1209 and 1211 [Thomas, 2004] and demonstrates the transition from a more radiogenic North Pacific deepwater mass to a less radiogenic Southern Ocean water mass beginning $\sim 45 \mathrm{Ma}$.

same water mass as the Shatsky Rise sites for a portion of its sedimentary history. Site 1215 is the northernmost in the Leg 199 transect, and it backtracks to $\sim 6^{\circ}$ south of the Shatsky Rise sites. Thus, on the basis of paleolatitude, it is reasonable that Site 1215 could have been influenced by the same water mass as Shatsky Rise. However, Site 1215 lies a considerable distance to the east of Shatsky
Rise. Deep water that formed in the North Pacific would have circulated to the south primarily in the western Pacific because of westward intensification. Because the lower limit of a North Pacifictype signature is only observed in three data points at Site 1215 and is not evident within the western tropical Pacific crust records (CLD01 and D11-1, for example), we suggest that the limit of the extent 
Table 2. Locations and Water Depths of All Drill Sites and Crusts Discussed in the Text

\begin{tabular}{|c|c|c|c|}
\hline Drill Site/Crust & Water Depth, m & Location & Reference \\
\hline Site 1209 & 2387 & $32^{\circ} 39^{\prime} \mathrm{N}, 158^{\circ} 30^{\prime} \mathrm{E}$ & Thomas [2004] \\
\hline Site 1211 & 2907 & $32^{\circ} 0^{\prime} \mathrm{N}, 157^{\circ} 51^{\prime} \mathrm{E}$ & Thomas [2004] \\
\hline Site 1215 & 5396 & $26^{\circ} 02^{\prime} \mathrm{N}, 147^{\circ} 56^{\prime} \mathrm{W}$ & this study \\
\hline Site 1217 & 5342 & $16^{\circ} 52^{\prime} \mathrm{N}, 138^{\circ} 06^{\prime} \mathrm{W}$ & this study \\
\hline Site 1219 & 5063 & $7^{\circ} 48^{\prime} \mathrm{N}, 142^{\circ} 01^{\prime} \mathrm{W}$ & this study \\
\hline Site 1221 & 5175 & $12^{\circ} 02^{\prime} \mathrm{N}, 143^{\circ} 42^{\prime} \mathrm{W}$ & this study \\
\hline $\mathrm{CB} 12$ & 2381 & $17^{\circ} 60^{\prime} \mathrm{N}, 178^{\circ} 39^{\prime} \mathrm{E}$ & Ling et al. [2005] \\
\hline CD29-2 & 2300 & $16^{\circ} 42^{\prime} \mathrm{N}, 168^{\circ} 14^{\prime} \mathrm{W}$ & Ling et al. [1997] \\
\hline CJ01 & 3082 & $17^{\circ} 59^{\prime} \mathrm{N}, 177^{\circ} 42^{\prime} \mathrm{W}$ & Ling et al. [2005] \\
\hline CLD01 & 2210 & $21^{\circ} 45^{\prime} \mathrm{N}, 160^{\circ} 44^{\prime} \mathrm{E}$ & Ling et al. [2005] \\
\hline D11-1 & 1800 & $11^{\circ} 39^{\prime} \mathrm{N}, 161^{\circ} 41^{\prime} \mathrm{E}$ & Ling et al. [1997] \\
\hline D137-01 & 7129 & $1^{\circ} 08^{\prime} \mathrm{S}, 168^{\circ} 04^{\prime} \mathrm{W}$ & van de Flierdt et al. \\
\hline VA13/2 & 4800 & $9^{\circ} 18^{\prime} \mathrm{N}, 146^{\circ} 03^{\prime} \mathrm{W}$ & Ling et al. [1997] \\
\hline
\end{tabular}

of a North Pacific deepwater mass existed somewhere between Shatsky Rise and Site 1215.

[24] The occurrence of Leg 199 values more radiogenic than the range of Shatsky Rise values at $\sim 38 \mathrm{Ma}$ (Sites 1217 and 1221) is likely due to differences in sampling and temporal resolution among the five records. The range of Shatsky Rise values is based on the upper and lower limits in the $\varepsilon_{\mathrm{Nd}}(\mathrm{t})$ values recorded at ODP Sites 1209 and 1211 [Thomas, 2004]. In this portion of the record, the sample spacing at Sites 1209 and 1211 ranges from 1.3 to $4.4 \mathrm{Ma}$. Thus it is possible that an increased temporal resolution in the Shatsky Rise records would eliminate the transient deviation between Sites 1217 and 1221 and the Shatsky Rise range in values. Regardless, since this deviation is only based on one analysis at each site we do not include this in our discussion of the longterm evolution of North Pacific deepwater mass composition.

[25] The original Shatsky Rise data were interpreted to reflect evidence for two distinct sources of deep water: one that is highly radiogenic that likely originated in the North Pacific, and a less radiogenic end-member derived from the Southern Ocean [Thomas, 2004]. While the presumed Southern Ocean end-member data are less radiogenic than the North Pacific end-member, they are still significantly more radiogenic than any other major ocean basin during the Paleogene [Thomas et al., 2003; Scher and Martin, 2004, 2006; Thomas, 2005; Via and Thomas, 2006]. The explanation for the relatively radiogenic $\mathrm{Nd}$ isotope values in the deep Pacific follows modern analogy. Radiogenic $\mathrm{Nd}$ is supplied to modern Pacific surface waters via weathering and drain- age of the circum-Pacific arc volcanics [Goldstein and Jacobsen, 1988]. As discussed in section 2.3, vertical exchange of $\mathrm{Nd}$ between Pacific surface and intermediate waters and the underlying deep and bottom water results in the relatively radiogenic $\varepsilon_{\mathrm{Nd}}$ signature (approximately -5 ) of the deep North Pacific despite the lack of downwelling in the region. The tectonic process that generated the arc volcanics, subduction of the Kula and Farallon Plates, had been underway at least since $\sim 110 \mathrm{Ma}$ [e.g., Larson and Pitman, 1972]. Thus the weathering of North Pacific terranes was likely the source of the most radio-

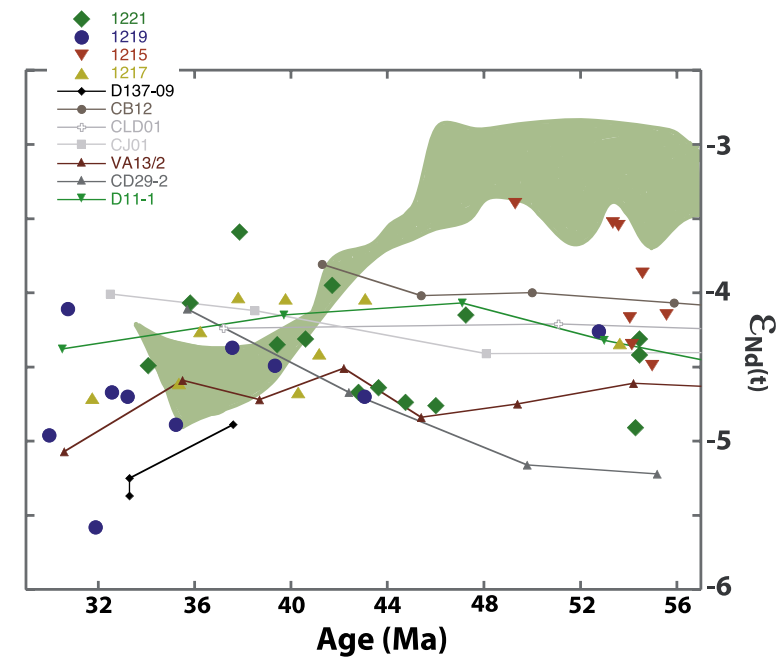

Figure 4. $\mathrm{Nd}$ isotope data versus age from the Leg 199 Sites and ferromanganese crust records D137-7 [van de Flierdt et al., 2004], CB12, CLD01, CJ01 [Ling et al., 2005], CD29-2, VA13/2, and D11-1 [Ling et al., 1997]. The light green shading represents the range of $\varepsilon_{\mathrm{Nd}}(\mathrm{t})$ values at Shatsky Rise Sites 1209 and 1211 [Thomas, 2004]. 
genic Nd to the surface waters of Late Cretaceous and early Paleogene oceans. By modern analogy, deep Pacific $\mathrm{Nd}$ isotope values in the range of approximately -4 to -5 recorded by the majority of the Leg 199 Sites and crusts likely resulted from radiogenic $\mathrm{Nd}$ scavenged from surface waters superimposed on deep waters with a relatively nonradiogenic source (e.g., approximately -8 to -9 from the Southern Ocean). Thus we assume that the relatively nonradiogenic $\varepsilon_{\mathrm{Nd}}$ endmember signature (e.g., less than approximately -4 epsilon units) was produced in the Southern Ocean during the early Paleogene [e.g., Thomas et al., 2003], although insufficient data exist to determine in which sector of the Southern Ocean these deep waters formed.

[26] The vertical extent of this Southern Ocean water mass in the ancient water column was from $\sim 1800 \mathrm{~m}$ to abyssal depths. The shallow end of this depth range is based on the present water depth of Crust D11-1 (1800 m), which was likely shallower early in its growth history because of thermal subsidence of the seamount from which it was dredged. The deep end-members are constrained by Crust D137-01 dredged from the Nova Canton Trough (7129 m present depth) and Crust VA13/2 $(4800 \mathrm{~m})$. There is no systematic depth stratification of $\mathrm{Nd}$ isotope values evident in the deep tropical Pacific that would suggest different deep and bottom water masses sourced from the Southern Ocean from 56 to $30 \mathrm{Ma}$.

[27] The occurrence of $\varepsilon_{\mathrm{Nd}}(\mathrm{t})$ values significantly more radiogenic than approximately -4 in equatorial Pacific deepwater values, particularly in a region far to the south of the radiogenic weathering inputs, implies a focused transfer of highly radiogenic surface waters to the deep ocean. This transfer of radiogenic Nd into the deep Pacific is most easily explained by downwelling of radiogenic waters in the North Pacific and advection to the south. The convergence of Site $1215 \varepsilon_{\mathrm{Nd}}(\mathrm{t})$ values toward the lower limit of those at Shatsky Rise suggests that the paleolocation of Site 1215 marked the maximum southern extent of the influence of a North Pacific deepwater mass. The depth range encompassed by a northern Pacific source extended from at least $2400 \mathrm{~m}$ (Site 1209) to $\sim 3600 \mathrm{~m}$ (Site 1215) by $49 \mathrm{Ma}$ (Figure 3). Prior to 53.6 Ma when Site 1215 first recorded a more radiogenic $\mathrm{Nd}$ isotope composition, either the North Pacific deepwater source did not reach Site 1215 or did not sink to the depth of Site 1215 at the time $(\sim 3300 \mathrm{~m}$; Figure 3$)$. It is interesting to note that one $\mathrm{Nd}$ isotope analysis from ODP Site 865 (present water depth 1500 m; present location $18^{\circ} 26^{\prime} \mathrm{N}, 179^{\circ} 33^{\prime} \mathrm{W}$, a bit to the south of northernmost crust record CLD01) was similar to Shatsky Rise values at $\sim 55.5 \mathrm{Ma}$ [Thomas et al., 2003]. However, the paleowater depth at Site 865 was less than $1500 \mathrm{~m}$ during the early Paleogene, placing it in the intermediatewater rather than the deepwater range. Thus we do not include it in our estimates of the influence of a North Pacific influence on deepwater mass composition. The next closest record in terms of latitude is Crust CLD01, located $11^{\circ}$ south of Shatsky Rise Sites 1209 and 1211, and $5^{\circ}$ south of Site 1215. This crust clearly records Nd isotope values less radiogenic than the inferred North Pacific deepwater mass [Ling et al., 2005]. Thus the best estimate of the southern limit of a North Pacific deepwater influence based on the available data lay between Site 1215 and Sites 1209 and 1211.

\subsection{Evolution of General Pacific Deepwater Circulation Patterns During the Paleogene}

[28] One important implication of the combined drill site and crust $\mathrm{Nd}$ isotope data set is that the deep tropical Pacific is characterized by $\varepsilon_{\mathrm{Nd}}(\mathrm{t})$ values more radiogenic than -6 throughout the Paleogene. The long-term existence of radiogenic $\mathrm{Nd}$ values in the deep Pacific relative to the other ocean basins implies that there was no significant contribution of deep waters from the Atlantic via the open Caribbean gateway. Deepwater $\varepsilon_{\mathrm{Nd}}(\mathrm{t})$ values from the North Atlantic, South Atlantic, and the Atlantic sector of the Southern Ocean were generally more negative than -8 during the late Paleocene and early Eocene ( 57 to $50 \mathrm{Ma})$ [Thomas et al., 2003]. Interestingly, the only available $\mathrm{Nd}$ isotope values from a Caribbean location during the Paleogene are five values from ODP Site $1001 \sim 55.5 \mathrm{Ma}$, and four of these values are far more radiogenic than even the deep Pacific (greater than -1) [Thomas et al., 2003]. This suggests that the deep waters in this part of the Caribbean received their $\mathrm{Nd}$ from drainage of the Caribbean volcanics and experienced little mixing with the Atlantic, further evidence that contributions from the deep Atlantic to the deep Pacific were not likely during the Paleogene. In fact, the deep Pacific may have influenced the deep Caribbean and Atlantic at times during the early Eocene, on the basis of several radiogenic excursions in the North Atlantic data sets, and a nonradiogenic 
excursion to -4.3 in the Caribbean [Thomas et al., 2003]. However, this speculation requires further testing.

[29] Without any significant contribution from the Atlantic during the Paleogene, deepwater circulation in the Pacific may have operated in a manner similar to the modern Atlantic from $\sim 65$ to $45 \mathrm{Ma}$. To be more precise, the available data suggests that the Pacific was characterized by bimodal production of deep waters in the high latitudes of both hemispheres. The location of the Southern Ocean source was likely in the Pacific sector, given that rifting of Australia from Antarctica did not permit deep flow until $\sim 33 \mathrm{Ma}$ [Stickley et al., 2004] and the prominent Kerguelen Plateau was likely an impediment to focused deepwater flow from the Atlantic or Indian sectors. Thomas [2004] suggested that Southern Ocean deep waters circulated at least as far north as Shatsky Rise Site 1209 prior to $\sim 65 \mathrm{Ma}$. The Pacific exhibited a bimodal pattern of deepwater formation with a North Pacific source of deep waters circulating as far south as Shatsky Rise from $\sim 65$ to $45 \mathrm{Ma}$ and possibly as far south as ODP Site 1215 from $\sim 54$ to $49 \mathrm{Ma}$.

[30] After $\sim 42 \mathrm{Ma}$, all the sites and crusts recorded $\mathrm{Nd}$ isotope values consistent with a single Southern Ocean source of deep water (with the exception of a single data point from Site 1221 as discussed above). However, the intensity and locus of Southern Ocean deepwater production likely varied throughout the Paleogene. The range of $\varepsilon_{\mathrm{Nd}}(\mathrm{t})$ values in the deep tropical Pacific influenced by the Southern Ocean is nominally defined in this work as lying between approximately -4 and -5.5 . For most of the Paleogene investigated in this work $(\sim 56$ to $36 \mathrm{Ma})$, the $\varepsilon_{\mathrm{Nd}}(\mathrm{t})$ range recorded in the deep tropical Pacific is found to lie between -4 and -5 . Yet after $36 \mathrm{Ma}$, the data trend toward less radiogenic values, particularly Site 1219 and Crust D137-01 and VA 13/2. Sites 1217 and 1221 also indicate more negative $\varepsilon_{\mathrm{Nd}}(\mathrm{t})$ values after $36 \mathrm{Ma}$, however these trends are less convincing given the overall variability exhibited prior to $36 \mathrm{Ma}$. Regardless, the trend toward somewhat less radiogenic values beginning $\sim 36 \mathrm{Ma}$ suggests a stronger contribution of waters with nonradiogenic values to the tropical deep Pacific.

[31] One possible explanation for a stronger imprint of nonradiogenic $\mathrm{Nd}$ to this region is intensification of deepwater production in the Southern Ocean as the Tasman Gateway broadened and deepened, and ice buildup and cooling progressed. An increase in the production and flow of deep- waters in the Southern Ocean may have caused hiatuses in the accumulation of drift deposits near the Chatham Rise and Campbell Plateau at the time of cooling and ice buildup at the Eocene/Oligocene boundary [Carter et al., 2004]. For example, ODP Site 1123 (northeastern edge of the Chatham Rise to the east of New Zealand) drilled during Leg 181 records the onset of drift deposition at the time of the Eocene-Oligocene boundary. Additional drift deposits cored during Leg 181 indicate significant increases in the flow of a Southern Ocean source of deep waters to the Pacific associated with the Eocene-Oligocene boundary, marking the advent of the Deep Western Boundary Current [Carter et al., 2004]. van de Flierdt et al. [2004] interpreted decreases in crust $\varepsilon_{\mathrm{Nd}}(\mathrm{t})$ values as an increase in the export of Southern Ocean deep waters to the deep Pacific, however their interpretations focused on the development and intensification of the Antarctic Circumpolar Current (ACC) during the early Miocene and did not extend back to the late Eocene-early Oligocene time period prior to the onset of ACC formation [Lyle et al., 2007].

[32] While $\mathrm{Nd}$ isotope data from Site 1219 and Crusts D137-09 and VA 13/2 suggest an increase in Southern Ocean deepwater production and flow likely associated with the intense cooling and ice buildup of the early Oligocene, the increase in $\varepsilon_{\mathrm{Nd}}(\mathrm{t})$ values at Site 1215 from $\sim 53.6$ to at least 49 Ma may have been related to a decrease in the production and flow of Southern Ocean deep waters relative to North Pacific deepwater production. This change coincides with the warmest climate interval of the early Eocene in the aftermath of the Paleocene-Eocene thermal maximum [Zachos et al., 2001]. It is not possible at this point to determine whether the relative change was due to a reduction in the flux of Southern Ocean deep waters, or intensified production and flow of North Pacific deep waters. Investigation of sites closer to the likely sources of downwelling in both regions is necessary to evaluate the nature of the change, and hence evaluate the relationship of the change to the climate record.

\section{Conclusions}

[33] The new ODP Leg $199 \mathrm{Nd}$ isotope data combined with the existing ferromanganese crust and fossil fish debris data from ODP Sites 1209 and 1211 help to constrain the evolution of water mass composition and structure of the deep Pacific during the Paleogene. The four sites $(1215,1217$, 1219 , and 1221) were ideally situated to monitor 
any contributions of deepwater from the Atlantic via the Caribbean gateway, and the data indicate no influence of Atlantic waters on the deepwater composition of the tropical Pacific. This finding corroborates the Pacific as a bimodal MOC system throughout the Paleogene, and the available deepwater $\mathrm{Nd}$ isotope data provide some limits on the geographic and depth range of influence of both a Southern Ocean and North Pacific deepwater mass. From $\sim 65$ to $\sim 45 \mathrm{Ma}$, the deep tropical Pacific was the mixing location of two main deepwater masses, one sourced from the Southern Ocean and the other from the North Pacific. The Southern Ocean deepwater mass extended vertically within the water column from $\sim 1800 \mathrm{~m}$ to abyssal depths, and circulated northward in the western Pacific at least as far as the paleolocation of Crust CLD01 $\left(\sim 5^{\circ} \mathrm{N}\right.$ paleolatitude $)$ and Site $1215\left(\sim 10^{\circ} \mathrm{N}\right.$ paleolatitude) in the eastern portion of the Pacific until 53.6 Ma. From 53.6 to at least $49.3 \mathrm{Ma}$, the extent of the influence of Southern Ocean deep waters shifted south, as Site 1215 recorded more radiogenic $\mathrm{Nd}$ isotope values inferred to have formed in the North Pacific. The North Pacific deepwater mass extended from at least $\sim 2400 \mathrm{~m}$ to $2900 \mathrm{~m}$ water depth from $\sim 65$ to $54 \mathrm{Ma}$, penetrating as far south as the Southern High of Shatsky Rise. A trend toward decreasing $\varepsilon_{\mathrm{Nd}}(\mathrm{t})$ values beginning at $\sim 36$ Ma may indicate the onset of the Deep Western Boundary Current as deepwater flow from the Southern Ocean intensified and the Tasman Gateway opened permitting flow from the west to enter the deep Pacific.

\section{Acknowledgments}

[34] D. T. would like to extend her continued gratitude to Drew Coleman for the use of the UNC Isotope laboratory. We all thank the reviewers and editorial staff for their helpful comments and assistance. M. L. was supported in part by NSF grant OCE0451291.

\section{References}

Amakawa, H., D. S. Alibo, and Y. Nozaki (2000), Nd isotopic composition and REE pattern in the surface waters of the eastern Indian Ocean and its adjacent seas, Geochim. Cosmochim. Acta, 64, 1715-1727.

Boyle, E. A. (1981), Cadmium, zinc, copper, and barium in foraminifera tests, Earth Planet. Sci. Lett., 53, 11-35.

Boyle, E. A., and L. D. Keigwin (1985), Comparison of Atlantic and Pacific paleochemical records for the last 250,000 years: Changes in deep ocean circulation and chemical inventories, Earth Planet. Sci. Lett., 76, 135-150.

Broecker, W. S., R. Gerard, M. Ewing, and B. C. Heezen (1960), Natural radiocarbon in the Atlantic Ocean, J. Geophys. Res., 65, 2903-2931.
Cande, S. C., and D. V. Kent (1995), Revised calibration of the geomagnetic polarity timescale for the Late Cretaceous and Cenozoic, J. Geophys. Res., 100, 6093-6095.

Carter, L., R. M. Carter, and I. N. McCave (2004), Evolution of the sedimentary system beneath the deep Pacific inflow off eastern New Zealand, Mar. Geol., 205, 9-27.

DePaolo, D. J., and G. J. Wasserburg (1976), Nd isotopic variations and petrogenetic models, Geophys. Res. Lett., 3, $248-252$.

Elderfield, H. R., J. Upstill-Goddard, and E. R. Sholkolvitz (1990), The rare earth elements in rivers, estuaries, and coastal seas and their significance to the composition of ocean waters, Geochim. Cosmochim. Acta, 54, 971-991.

Goldstein, S. L., and S. B. Jacobsen (1988), Nd and Sr isotope systematics of river water suspended material: Implications for crustal evolution, Earth Planet. Sci. Lett., 87, 249-265.

Halliday, A. N., J. P. Davidson, P. Holden, R. M. Owen, and A. M. Olivarez (1992), Metalliferous sediments and the scavenging residence time of $\mathrm{Nd}$ near hydrothermal vents, Geophys. Res. Lett., 19, 761-764.

Harrison, C. G. A., and T. Lindh (1982), A polar wandering curve for North America during the Mesozoic and Cenozoic, J. Geophys. Res., 87(B3), 1903-1920.

Jeandel, C. (1993), Concentration and isotopic composition of $\mathrm{Nd}$ in the South Atlantic Ocean, Earth Planet. Sci. Lett., 117, 581-591.

Jeandel, C., D. Thouron, and M. Fieux (1998), Concentration and Atlantic isotopic compositions of neodymium in the eastern Indian Ocean and Indonesian straits, Geochim. Cosmochim. Acta, 62, 2597-2607.

Larson, R. L., and W. C. Pitman III (1972), Worldwide correlation of Mesozoic magnetic anomalies and its implications, Geol. Soc. Am. Bull., 83, 3645-3661.

Levitus, S. (1982), Climatological Atlas of the World Ocean, NOAA Prof. Pap. 13, 173 pp., U.S. Govt. Print. Off., Washington, D. C.

Ling, H. F., K. W. Burton, R. K. O'Nions, B. S. Kamber, F. von Blanckenburg, A. J. Gibb, and J. R. Hein (1997), Evolution of $\mathrm{Nd}$ and $\mathrm{Pb}$ isotopes in central Pacific seawater from ferromanganese crusts, Earth Planet. Sci. Lett., 146, 1-12.

Ling, H. F., S.-Y. Jiang, M. Frank, H.-Y. Zhou, F. Zhou, Z.-L. Lu, X.-M. Chen, Y.-H. Jiang, and C.-D. Ge (2005), Differing controls over the Cenozoic $\mathrm{Pb}$ and $\mathrm{Nd}$ isotope evolution of deepwater in the central North Pacific Ocean, Earth Planet. Sci. Lett., 232, 345-361.

Lyle, M., et al. (2002), Proceedings of the Ocean Drilling Program, Initial Reports, vol. 199, doi:10.2973/odp.proc. ir.199.2002, Ocean Drill. Program, College Station, Tex.

Lyle, M., S. Gibbs, T. C. Moore, and D. K. Rea (2007), Late Oligocene initiation of the Antarctic Circumpolar Current: Evidence from the South Pacific, Geology, 35, 691-694.

Martin, E. E., and B. A. Haley (2000), Fossil fish teeth as proxies for seawater $\mathrm{Sr}$ and Nd, Geochim. Cosmochim. Acta, 64, 835-847.

Martin, E. E., and H. D. Scher (2004), Preservation of seawater $\mathrm{Sr}$ and $\mathrm{Nd}$ isotopes in fossil fish teeth: Bad news and good news, Earth Planet. Sci. Lett., 220, 25-39.

Moran, K., et al. (2006), The Cenozoic palaeoenvironment of the Arctic Ocean, Nature, 441, 601-605.

Mountain, G. S., and K. G. Miller (1992), Seismic and geologic evidence for late Paleocene - early Eocene deepwater circulation in the western North Atlantic, Paleoceanography, 7, 423-439.

Pak, D. K., and K. G. Miller (1992), Paleocene to Eocene benthic foraminiferal isotopes and assemblages: Implications for deepwater circulation, Paleoceanography, 7, 405-422. 
Pares, J. M., and T. C. Moore (2005), New evidence for the Hawaiian hot spot plume motion since the Eocene, Earth Planet. Sci. Lett., 237, 951-959.

Piepgras, D. J., and S. B. Jacobsen (1988), The isotopic composition of neodymium in the North Pacific, Geochim. Cosmochim. Acta, 52, 1373-1381.

Piepgras, D. J., and G. J. Wasserburg (1982), Isotopic composition of neodymium in waters from the Drake Passage, Science, 217, 207-214.

Piepgras, D. J., and G. J. Wasserburg (1987), Rare earth element transport in the western North Atlantic inferred from $\mathrm{Nd}$ isotopic observations, Geochim. Cosmochim. Acta, 51, $1257-1271$.

Reynard, B., C. Lecuyer, and P. Grandjean (1999), Crystalchemical controls on rare-earth element concentrations in fossil biogenic apatites and implications for paleoenvironmental reconstructions, Chem. Geol., 155, 233-241.

Scher, H. D., and E. E. Martin (2004), Circulation in the Southern Ocean during the Paleogene inferred from neodymium isotopes, Earth Planet. Sci. Lett., 228, 391-405.

Scher, H. D., and E. E. Martin (2006), Timing and consequences of the opening of Drake Passage, Science, 312, $428-430$.

Shaw, H. F., and G. J. Wasserburg (1985), Sm-Nd in marine carbonates and phosphates, Geochim. Cosmochim. Acta, 49, $503-518$.

Shimizu, H., K. Tachikawa, A. Masuda, and Y. Nozaki (1994), Cerium and neodymium isotope ratios and REE patterns in seawater from the North Pacific Ocean, Geochim. Cosmochim. Acta, 58, 323-333.

Sholkovitz, E. R. (1993), The geochemistry of rare earth elements in the Amazon River estuary, Geochim. Cosmochim. Acta, 58, 2181-2190.

Staudigel, H., P. Doyle, and A. Zindler (1985), Sr and Nd isotope systematics in fish teeth, Earth Planet. Sci. Lett., $76,45-56$.

Stickley, C. E., H. Brinkhuis, S. A. Schellenberg, A. Sluijs, U. Röhl, M. Fuller, M. Grauert, M. Huber, J. Warnaar, and G. L. Williams (2004), Timing and nature of the deepening of the Tasmanian Gateway, Paleoceanography, 19, PA4027, doi:10.1029/2004PA001022.

Tachikawa, K., C. Jeandel, and M. Roy-Barman (1999), A new approach to the $\mathrm{Nd}$ residence time in the ocean: The role of atmospheric inputs, Earth Planet. Sci. Lett., 170 , $433-446$

Tanaka, T., et al. (2000), JNdi-1: A neodymium isotopic reference in consistency with LaJolla neodymium, Chem. Geol., 168, 279-281.

Thomas, D. J. (2004), Evidence for production of North Pacific Deep Waters during the early Cenozoic greenhouse, Nature, 430, 65-68.

Thomas, D. J. (2005), Reconstructing ancient deep-sea circulation patterns using the $\mathrm{Nd}$ isotopic composition of fossil fish debris, in Isotopic and Elemental Tracers of Late Cenozoic Climate Change, edited by D. Surge and G. Mora, Spec. Pap. Geol. Soc. Am., 395, 1-12.

Thomas, D. J., and R. K. Via (2007), Neogene evolution of Atlantic thermohaline circulation: Perspective from Walvis Ridge, southeastern Atlantic Ocean, Paleoceanography, 22, PA2212, doi:10.1029/2006PA001297.

Thomas, D. J., T. J. Bralower, and C. E. Jones (2003), Neodymium isotopic reconstruction of late Paleocene-early Eocene thermohaline circulation, Earth Planet. Sci. Lett., 209, 309-322.

Tomczak, M., and J. S. Godfrey (1994), Regional Oceanography: An Introduction, 422 pp. Pergamon, London.

van de Flierdt, T., M. Frank, J. R. Hein, B. Hattendorf, D. Gunther, and P. W. Kubik (2004), Deep and bottom water export from the Southern Ocean to the Pacific over the past 38 million years, Paleoceanography, 19, PA1020, doi:10.1029/2003PA000923.

Via, R. K., and D. J. Thomas (2006), Evolution of Atlantic thermohaline circulation-Early Oligocene onset of deepwater production in the North Atlantic, Geology, 34, 441444.

Wright, J., R. S. Seymour, and H. Shaw (1984), REE and Nd isotopes in conodont apatite: Variations with geological age and depositional environment, Spec. Pap. Geol. Soc. Am., 196, 325-340.

Wright, J. D., and K. G. Miller (1996), Control of North Atlantic Deep Water circulation by the Greenland-Scotland Ridge, Paleoceanography, 11, 157-170.

Zachos, J. C., M. Pagani, L. C. Sloan, E. Thomas, and K. Billups (2001), Trends, rhythms, and aberrations in global climate 65 Ma to present, Science, 292, 686-693. 